\title{
Commensal Rodents in 19th Century Australasia: Diversity, Invasion Routes and the China Connection
}

Andrew James Veale ( $\nabla$ andrew.j.veale@gmail.com )

Manaaki Whenua: Landcare Research New Zealand https://orcid.org/0000-0002-9405-272X

Carolyn King

University of Waikato School of Science

Wayne Johnson

Place Management NSW

Lara Shepherd

Museum of New Zealand Te Papa Tongarewa

\section{Research Article}

Keywords: Commensal rodents, diversity, invasion, DNA

Posted Date: May 11th, 2021

DOI: https://doi.org/10.21203/rs.3.rs-339763/v1

License: (9) This work is licensed under a Creative Commons Attribution 4.0 International License.

Read Full License 


\section{Commensal rodents in $19^{\text {th }}$ century Australasia: diversity, invasion routes and the China connection}

Veale, Andrew J. ${ }^{1}$; King, Carolyn M. ${ }^{2}$; Johnson, Wayne. ${ }^{3}$; Shepherd, Lara. ${ }^{4}$

1) Manaaki Whenua Landcare Research, 231 Morrin Rd, St Johns, Auckland 1072. andrew.j.veale@gmail.com. Corresponding author.

2) University of Waikato, School of Science, Hamilton 3240. cmking@waikato.ac.nz

3) Place Management NSW, PO Box N408, Grosvenor Place NSW 122. wayne.johnson@property.nsw.gov.au

4) Museum of New Zealand Te Papa Tongarewa, PO Box 55, Cable Street, Wellington 601, New Zealand. Lara.Shepherd@tepapa.govt.nz

Orcid IDs:

Andrew Veale: 0000-0002-9405-272X

Carolyn King: 0000-0001-6048-8931

Lara Shepherd: 0000-0002-7136-0017

\section{Abstract}

The present genetic diversity of commensal rodent populations is often used to inform the invasion histories of these species, and as a proxy for historical events relating to the movement of people and goods. These studies assume that modern genetic diversity generally reflects early colonising events. We investigate this idea by sequencing the mitochondrial DNA of rodent bones found in a $19^{\text {th }}$-century archaeological site in The Rocks area of Sydney, Australia, the location of the first historical European port. We identified $19^{\text {th }}$-century bones from two species, Rattus norvegicus and Mus musculus domesticus. We found six genetic haplotypes in the 39 Norway rats, showing either multiple early introductions or a diverse initial founding population. One of them was identical with Norhap01 common in the North Island of New Zealand, but none was like the haplotype Norhap02 found throughout the South Island. We found three haplotypes in seven house mice, all belonging to the dominant subspecies established in Australia, M.m. domesticus. There was no evidence for $M . m$. castaneus or M. m. musculus having established there. We had few modern $R$. norvegicus and M. musculus DNA sequences from Sydney, but those we had did tentatively support the hypotheses that (1) modern samples can represent at least a preliminary estimate of historical diversities and origins, and (2) Asian haplotypes of both Norway rats and of house mice reached the South Island of New Zealand early in colonial times direct from China rather than through Port Jackson. 


\section{Declarations}

\section{Funding}

Funding for the genetics analysis was provided by Waikato University's Strategic Investment Fund, courtesy Prof Bruce Clarkson.

\section{Conflicts of interest}

None

\section{Availability of data and material}

All sequences will be uploaded to Genbank upon acceptance

\section{Code availability}

Not Applicable

\section{Authors' contributions}

A. J. Veale helped conceive the study, performed lab work, performed the analyses, created the figures and wrote the first draft of the paper.

C. M. King conceived the study, obtained funding, and helped write and edit the paper. W. Johnson curated and interpreted the archaeological samples and helped edit the paper.

L. Shepherd performed the ancient DNA lab work, helped assemble the sequences, and helped edit the paper.

All authors read and approved the final manuscript.

\section{Ethics approval}

Thanks to the State Library of NSW for permission to reproduce the photo in Figure 4.

\section{Consent to participate}

All authors read and approved the final manuscript and consent to their participation.

\section{Consent for publication}

All authors consent to the publication of the article in Biological Invasions when accepted. 


\section{Introduction}

Commensal rats and mice, particularly the brown rat (Rattus norvegicus), the ship (black) rat (Rattus rattus) and the house mouse (Mus musculus), are the most widespread and destructive invasive vertebrates around the world (Genovesi et al. 2012; Howald et al. 2007; Pimentel et al. 2000). Because commensal rodents have a close relationship with humans, having travelled around the world with us, their distributions can often tell us more about our own history than can the sparse documentary records available (Brouat et al. 2014; Gabriel et al. 2015; Gabriel et al. 2011; Jones et al. 2013; Jones et al. 2011; Jones et al. 2012; Li et al. 2020). Also, the history of rodent invasions can reveal answers to broad questions relating to their ecology and evolution, and to how invasive populations are founded and maintained.

Two particular questions relevant to invasion biology in general are potentially answerable by examining invasive rodent populations: 1) are islands typically invaded once followed by population expansion, or are invasive populations established through multiple introductions?; and 2) can the genetic variation of contemporary populations accurately describe the founding and ongoing population history of the invaders?.

Invasive rodent species are often capable of explosive population growth. Single invasions can populate entire islands, or even whole continents, if given time or assistance via human traffic. Once established, the priority advantages of these founding populations may enable them to exclude subsequent invaders entirely, or swamp any genetic admixture from other source populations or lineages (Combs et al. 2017; Fraser et al. 2015; Puckett et al. 2016). Alternatively, new waves of rodents could establish or even overtake earlier founders, either because the new immigrants carry genetic variations more suited to the location, or because of stochastic events in the original population allowing novel immigrants space to establish.

Generally, older invasions are poorly documented, so the only information available about their origins have been incomplete or are known only from apocryphal historical narratives. Now, many rodent invasion histories can be interpreted through population genetic analysis of their contemporary descendants (Jones et al. 2013; Searle 2008; Searle et al. 2009a; Searle et al. 2009 b). The key question, however, remains: how well does contemporary genetic diversity reflect the historical diversity and trends of the original invaders?

Australia, and particularly Port Jackson, the first wharf area of Sydney, presents an ideal location to investigate these questions. Port Jackson was the point of arrival for many of the European-introduced invading rodent species now present, and their remains can be recovered from well preserved stratified archaeological deposits. They joined the indigenous fauna of Australia, which includes both marsupial 'rodent-like' small mammals, and a diverse range (64 species) of indigenous placental true rodents (Geffen et al. 2011). These native rodents include seven species of the genus Rattus, such as the bush rat $R$. fuscipes, a species that was probably common in the Sydney area prior to forest clearance and European settlement (Banks et al. 2012). There are also four species of introduced murid rodents in Australia: brown rats, ship (black) rats, pacific rats (Rattus exulans) and house mice.

Brown rats were the dominant rat in stores and warehouses in Europe up until the 1850s, and are thought to be the species most commonly spread around the world on ships at that time (Atkinson 1973); therefore they probably arrived early in Australia. Rat damage to stores and equipment was a serious issue from the earliest days of settlement at Sydney Cove. 
Sydney newspapers were reporting problems with rats as vermin from as early as 1803 (Anon. $1803,1804)$, but there are very few formal records of which rat species was responsible. The first record that can be attributed specifically to $R$. norvegicus in Australia was by Clutterbuck (1850) who noted the presence of the 'brown rat' in Melbourne in the late $1840 \mathrm{~s}$, but $R$. norvegicus was certainly present in both Australia and New Zealand long before then. Brown rats are now common commensal pests in the urban and suburban areas of metropolitan cities in both countries, particularly around heavily modified areas and the coast (Menkhorst 1995; Robinson et al. 2000; Russell, Innes 2021; Seebeck, Menkhorst 2000).

Ship rats became the major ship-borne species of rodent only after the 1830s-1850s (Atkinson 1973). They could have reached Australia as early as the 1600s (Archer 1984), but did not establish resident populations until decades after permanent European settlement began in the late 1780s (Banks, Hughes 2012; Long 2003). The earliest definite $R$. rattus specimens from Australia are dated to the $1840 \mathrm{~s}$, but most specimens are from the 1870s or later (Banks, Hughes 2012). By 1900, ship rats were very abundant across the city of Sydney (Banks et al. 2012; Curson, McCracken 1989).

House mice probably arrived in Australia with early European explorers and settlers during the late 18th century (Gabriel et al. 2011; Long 2003; Searle et al. 2009a; Watts, Aslin 1981). The earliest archaeological specimens of house mice in Australia were found in the Hyde Park Barracks Destitute Asylum in Sydney, dating from the period 1848-1886 (Davies, Garvey 2013). All mice so far sequenced from Australia have belonged to the subspecies $M$. $\mathrm{m}$. domesticus (Gabriel et al. 2011; Veale et al. 2018). The majority represent Clade E, including almost all mice from the Sydney area. Clades B, F, and D are present elsewhere in Australia, and clade F mice dominate the arid interior (Gabriel et al. 2011).

Clade E of $M . m$. domesticus is strongly represented in New Zealand, as would be expected if most mice reached the southern Pacific area from Britain (King 2016). New Zealand mice also carry traces of the two other subspecies $M . m$. musculus, and $M . m$. castaneus both resident in east Asia (King et al. 2016; Veale et al. 2018). Most commercial shipping to New Zealand came via Sydney, but M. m. musculus and M. m. castaneus have so far never been detected there. How then did these non-European subspecies of mice get to New Zealand?

During earliest colonial times, the Chinese port of Canton was the centre of an international fur market and an important regional hub for European and American shipping. Either they made their way independently to New Zealand direct from Canton, probably with returning sealers, or they were present in Port Jackson at some point in the past (and could be still present but undetected). Documenting the genetic makeup of historical samples of rodents from the ports of Sydney could help us distinguish between these possibilities, and better understand the timing and invasion history of mice and rats in the southern Pacific (King 2016).

The earliest private Sydney wharves were built in Campbell's Cove on the west coast of Port Jackson, and the first settlement began there, in the area known as The Rocks, in the late eighteenth century (Kelly 1997). The infant city of Sydney grew rapidly, and over the next hundred years developed into a rambling, tight-packed mass of houses, wharves and sheds. Standards of construction and sanitation were minimal or absent. The wealthy merchant class were insulated from the noise and stink in their grand mansions, while their working-class waterside workers lived in overcrowded squalor. 
Such conditions were ideal for rats, many of which carried the common rat flea (Xenopsylla cheopis). Rats were easily imported into Sydney with merchandise from around the world (Hainsworth 1972). Eventually, some of those rats also carried fleas infested with the pathogen that causes bubonic plague (Yersinia pestis). In 1900, an outbreak of bubonic plague stimulated 'alarm bordering on panic', and not only in Sydney. The potential for rapid international spread of this greatly-feared disease is illustrated by the 21 cases of plague and nine deaths that were reported in New Zealand between 1900 and 1911, mostly from the Auckland district (McLean 1955).

The New South Wales Government took the chance to redevelop the waterfront, by 'resuming' control of The Rocks area (i.e., by forced purchase, and in some cases, eviction of all residents) and demolishing whole streets of buildings. In other buildings left standing, the floors were torn up and loads of sterile soil laid over the rubbish that had accumulated between and under the floor boards. Back yards were usually covered in bitumen. So archaeological deposits dating from before the plague were sealed, and the rebuilding began from on top of the ruins (Kelly 1997).

Between May 1994 and October 1996 the then Sydney Cove Authority undertook extensive excavations among the foundations of old buildings in Cumberland and Gloucester Streets. Over 750,000 artefacts were recovered from the remains of 46 separate buildings, analysed and catalogued in great detail. Each item or group of small items from the same deposit was placed in a separate, labelled zip-lock bag, and stored in meticulously documented detail in boxes kept in a storage facility in Darling Harbour (Figure 1A). They now form a major part of The Rock's historic artefact collection.

The phylogeny of the rats and mice that have reached NZ during historic times is known, at least to a first approximation, from recently published analyses. But there are no current hard data to confirm the present assumption (from shipping data and historical observations) that ship rats did not reach the southwest Pacific until the mid 19th century. Likewise, the conclusion from current DNA data that the eastern haplotype of the house mouse Mus musculus castaneus could have reached New Zealand direct from China rather than passing through Sydney (King et al. 2016; King 2016), has not been tested by further sampling from Sydney. If true, both these propositions have implications for understanding both invasion history of commensal rodents in the south Pacific, and the early commercial history of pre-colonial New Zealand.

In short, the biological evidence challenges the usual assumption that all commensal rodents that reached NZ between 1788 and 1900 came from, or passed through, Sydney. Therefore, it would be of great interest for NZ historians and pest managers to identify the species represented in Sydney's 19th-century dockland.

\section{Our aims}

In this study we aimed to better understand the invasion history and trends in the genetic diversity and origins of commensal rodents in the port area of Sydney since European settlement began. Specifically, we expected to 1) determine the earliest record of each rodent species appearing in the archaeological record, 2) search for traces of $M . m$. castaneus or $M$. m. musculus in Sydney, and 3) understand the temporal dynamics of the genetic diversity of the rodent species present. For example, are new haplotypes appearing, or is the genetic makeup of an invasive population reasonably static after it is founded? 


\section{Material and Methods}

\section{Archaeological sampling}

All items recovered from the 1994-1996 excavation at The Rocks were listed in a massive database, under 5-digit specimen numbers and general categories including "Bone". The rodent component $(<1 \%$ of $>100,000$ items recovered) was usually identified simply as "Rodent", and roughly dated from archaeological information. In the Archaeological report of the site (Kelly et al. 1996) deposits were classified into one or more of the following 11 stages:

Phase 1: Pre-1788 - Pre-European Occupation

Includes all deposits in existence before European Settlement. This includes bedrock and subsoil deposits. Pre-contact cultural material associated with the Aboriginal occupation of the site is included in this phase.

Phase 2: 1788 - c.1810 - Early European Occupation

European occupation or use of the site prior to the formalisation of the various properties during the Macquarie Period. The phase includes contact, clearance as well as irregular occupation by Europeans. The initial Byrne family occupancy falls within this period and extends into the following periods.

Phase 3: c. 1810 - c.1833 - Formal land Division

Formal alienation of land and Cribb occupancy of the southern half of the site. Sub-division of the Gloucester Street frontage with the development of residences and dwellings.

Phase 4: c.1833-c.1851 - Early Sub-division and Occupation

Sub-division of part of southern half of site along Cumberland Street, extension of Byrne House, further development along Gloucester Street.

Phase 5: c.1851 - c.1860 - Further Sub-division and Occupation

This phase was instituted in order to break the post-1850 period (29 years) into two smaller units. During this phase sub-divisions were registered on the southern half of the site under Massey and in the Byrne property in the north resulting in the construction of the Cribbs LaneCarahers Lane Terraces.

Phase 6: c. 1880 - c.1900 - Intensive Occupation and decline

The final phase of the sites' development functioned as a residential community until the outbreak of the Plague, characterised by close settlement and possible break-down of service infrastructure.

Phase 7: c. 1900 - c.1916 - "Plague" Clearances

Visitation of the Plague. Gradual removal of dwellings, levelling of the site and the introduction of fill and bitumen covering in some areas.

Phase 8: c 1916 - c 1924 - Engineering Works

Use of site as both Engineering works, railway workshop and training facility.

Phase 9: c.1924 - c.1950 - Post-Engineering Works Occupancy

Use of site as motor garage and other undetermined uses. 
Phase 10: c. 1950 - c 1972 - Bus Depot

Removal of structures and installation of concrete slab over site for use as a bus parking depot.

Phase 11: c. 1972 - c.1994 - Sydney Cove Authority

Control of the site by the Sydney Cove Redevelopment Authority, later the Sydney Cove Authority. Little change to the physical structure of the site apart from dumping along eastern margin.

Because it was impossible to date each of the deposits precisely, most samples were assigned to a broad range crossing several of these phases, unless they were collected from a specific place such as a well that was sealed at a known date. In general, these rodent bones consisted of disarticulated elements within deposits, with no apparent evidence of nests that may have been burrowed down from later deposits.

Rodent bones from the same level and date were stored together in separate bags in the same boxes after recovery from the archaeological site. Box and bag numbers were linked to the database. Provisional identifications were written by the excavators on the database printout, subject to DNA verification. We used forceps to remove a few bones from each bag, making a representative set of 120 samples of rat bones and 15 of mouse bones, concentrating on the earlier phases of occupation. These specimens were imported into New Zealand in new, separate sealed plastic bags, under a permit from the University of Waikato, where they were held in a biosecure facility. From there they were sent on to the ancient DNA laboratory at Museum of New Zealand Te Papa Tongarewa.

\section{DNA extraction and amplification}

All DNA extractions and PCR set-ups were performed in an ancient DNA laboratory at the Museum of New Zealand Te Papa Tongarewa, which is physically isolated from the locations where modern DNA and PCR products are handled. Potential contamination was monitored by the use of negative extraction and PCR controls.

DNA was extracted from a single whole bone from each specimen. Bones were ground to a fine powder in a mortar and pestle before extraction using the method described in Wood et al. (2016), except that DNA was eluted in a final volume of $50 \mu \mathrm{l}$ of Buffer AE. Mortar and pestles were cleaned with bleach and UV-irradiated between samples.

Rat-specific and mouse-specific primers (Table 1) were designed using Primer 3 (Rozen, Skaletsky 2000) to amplify short overlapping fragments ( $\leq 140 \mathrm{bp}$ ) of the mitochondrial Dloop. We designed the rat primers to sit within mitochondrial regions conserved between Rattus rattus and Rattus norvegicus. We expected to find that the majority of amplified D-loop variation in Sydney samples of both of these species to be similar to those recorded in a recent study of the mitochondrial genetic diversity of both species across New Zealand, because the diversities present in the two neighbouring countries are likely to be similar (Russell et al. 2019). Similarly, we designed the mouse primers to sit within regions of the mitochondrial Dloop conserved between the three subspecies of Mus musculus (M. m. musculus, M. m. domesticus, and M. m. castaneus), amplifying the majority of D-loop variation recorded in recent studies of mice from New Zealand and Australia (King et al. 2016; Veale et al. 2018). 
Each DNA extract was initially amplified with rat-specific primers, as most of the bones were expected to represent rats, from their size and morphology. All extracts that failed to amplify were then amplified with the mouse-specific primers.

PCR amplifications were performed in $12 \mu$ l volumes containing 1× MyTaq mix (Bioline, Australia), $0.3 \mathrm{M}$ of BSA and $0.5 \mu \mathrm{M}$ of each primer. For all PCR amplifications the thermocycling conditions involved an initial denaturation of $98^{\circ} \mathrm{C}$ for 1 minute then 45 cycles of $98^{\circ} \mathrm{C}$ for $20 \mathrm{~s}, 50^{\circ} \mathrm{C}$ for $20 \mathrm{~s}$ and $72^{\circ} \mathrm{C}$ for $30 \mathrm{~s}$, followed by a final extension of $72^{\circ} \mathrm{C}$ for 5 $\min$.

PCR products were purified by digestion with $0.5 \mathrm{U}$ shrimp alkaline phosphatase (rSAP; New England Biolabs, Massachusetts, USA) and 2.5 U exonuclease I (Exo I; New England Biolabs, Massachusetts, USA at $37^{\circ} \mathrm{C}$ for $15 \mathrm{~min}$, followed by inactivation of the enzymes by $15 \mathrm{~min}$ at $80^{\circ} \mathrm{C}$. DNA sequencing was performed in both directions by capillary separation at Macrogen (Seoul, South Korea) and the resulting sequences were edited in Sequencer 5.4.6 (Gene Codes Corporation).

Along with the historical samples, we obtained three modern $R$. norvegicus specimens collected from near the University of Sydney two kilometres from the city centre. From their tail samples, DNA was extracted in the Ecogene lab at Manaaki Whenua Landcare Research in Auckland using the DNeasy Tissue Kit (Qiagen). The whole $585 \mathrm{bp}$ amplicon of the DLoop was amplified with the primers EGL4L and RJ3R (Robins et al. 2007). The reaction volume was $20 \mu \mathrm{L}$ comprising: $10 \mathrm{mM}$ Tris $\mathrm{HCl} \mathrm{pH} 8.3 ; 50 \mathrm{mM} \mathrm{KCl}, 2.5 \mathrm{mM} \mathrm{MgCl} 2$, primers at $0.5 \mu \mathrm{M}$ each, dNTPs at $0.15 \mathrm{mM}$ each; $0.5 \mathrm{U}$ of Taq polymerase, $1 \mu \mathrm{L}$ of DNA template. The PCR (polymerase chain reaction) regime was an initial denaturation step of $94^{\circ} \mathrm{C}$ for $2 \mathrm{~min} ; 35$ cycles of $94^{\circ} \mathrm{C}$ for $30 \mathrm{~s}, 60^{\circ} \mathrm{C}$ for $30 \mathrm{~s}$ and $72^{\circ} \mathrm{C}$ for $1 \mathrm{~min}$ with a final extension step of $72^{\circ} \mathrm{C}$ for 5min. PCR products were visualized and quantified, using a low mass ladder for comparison, on ethidium bromide stained 1\% agarose gels. PCR products were purified with ExoSAP-IT (Affymetrix, Inc.). Sequencing was carried out at the Ecogene lab in Auckland using the BigDye Terminator version 3 sequencing kit, the GeneAmp PCR System 9700 and a capillary ABI3730 DNA analyzer, all from Applied Biosystems.

\section{Genetic Analyses}

All sequences were imported into Geneious (Kearse et al. 2012), where we trimmed off the primer sequences, then aligned all modern and historical sequences for each species, along with the New Zealand mouse haplotypes from King et al. (2016) and the rat haplotypes from Russell et al. (2019). We then created haplotype networks for each species using the R packages ape (Paradis et al. 2004; Paradis, Schliep 2019) and pegas (Paradis 2010). We also created plots showing the distribution of these haplotypes over time using the R package ggplot2 (Wickham 2016).

\section{Results}

Of the 120 samples that were subsampled from the excavated material, 39 rat samples (all $R$. norvegicus) amplified and 7 mouse samples (all M. m. domesticus) amplified (all of these amplified across all primer sets). We found no traces of ship rats or any of the native rats. 
Of the $R$. norvegicus material, 31 out of the 39 samples yielding DNA sequences were excavated from layers laid down before 1900, most from deposits dated between 1851 and 1900. Fifteen samples were from deposits potentially laid down before 1851, of which only one could be clearly dated to before 1880 and two could be as old as 1788 . We found a total of seven $R$. norvegicus D-loop haplotypes, labelled here with numbers 5, 7-12, of which four were separated by only one base pair.

In the haplotype network (Figure 2) we have included the six $R$. norvegicus haplotypes labelled 1-6 identified in New Zealand by (Russell et al. 2019). Haplotypes 1, 2 and 6, recorded only in New Zealand, are uncoloured, so as to facilitate later discussions of connections between the two countries. No other wild $R$. norvegicus $\mathrm{D}$-loop sequences have previously been obtained from Australia. Among the three modern samples, we recorded three different haplotypes, two of which were also recorded in the historical samples (haplotypes $9 \& 5$ ) and one novel haplotype (3) that differed from haplotype 5 by only one base pair.

Comparing the archaeological layer from which each sample was excavated with the genetic haplotypes found there shows that most of the samples can be dated to the period $1850-1900$, with only a few from earlier or later layers (Figure 3 ). The absence of precise dates for most of the samples made it hard to extrapolate trends in the times when each haplotype first arrived and was last recorded, and the paucity of modern samples prevents any firm documentation of which haplotypes still remain present. What is evident from these results, however, is that at least six D-loop haplotypes for $R$. norvegicus were present in the Rocks area in the latter half of the $19^{\text {th }}$ Century.

Among the historical M. m. domesticus samples, three haplotypes were present, all representing clade E. In the haplotype network in Figure 2 the single base-pair difference between haplotypes A and B is not shown, as this variable site was located in a region of D-loop that was not amplified by (Gabriel et al. 2011). We therefore trimmed this region of the figure, as we do not know which of these two sequences is closer to the original ones. Similarly, the single base pair difference between Australia.01 and Australia.04 of (Gabriel et al. 2011) was not amplified in our dataset, therefore these two haplotypes are merged into one, both matching our haplotypes A and B. We found no traces of M. m. musculus or M. m. castaneus in this sample.

\section{Discussion}

\section{Rat species in Sydney}

There have been no systematic studies of the distribution and densities of rat species across Sydney, except some limited to specific focal sites in the peripheral suburbs (e.g. (Cox, Cox 2001; Rose, Banks 2007; Smith et al. 2016). Anecdotally, $R$. norvegicus is currently the most common rat in the Sydney city centre, while $R$. rattus is more likely to be present in the suburbs and bushland (Peter Banks pers. comm.).

The domination of $R$. norvegicus at the archaeological site is unsurprising. Robinson et al. (2000) describe the current distribution of $R$. norvegicus in Australia as being "restricted to the vicinity of human habitation in coastal cities... particularly in port areas, .....warehouses, wharves, rubbish dumps and degraded creeks." The Rocks area was certainly ideal $R$. norvegicus habitat throughout the period sampled. 
In a photograph taken of a pile of dead rats collected from within the quarantine area during the plague outbreak in 1900, most appear to be $R$. norvegicus, along with some $R$. rattus, the native bush rat $R$. fuscipes and at least one rakali (Hydromys chrysogaster), a native Australian water rat with a white tail tip, seen in the lower right of the picture (Figure 4).

Figure 4 is very useful, but must not be interpreted at face value. There was a bounty on rats at the time, and some of the species present in the picture (particularly $R$. fuscipes) are unlikely to have lived in the central industrialised district of Sydney. Bounty operations commonly encourage trappers to bring in animals from elsewhere in order to collect the bounty. The only rat bones that we genetically identified were from $R$. norvegicus: there was no evidence of $R$. rattus, or $R$. fuscipes in the deposits from the Sydney Cove archaeological site.

While our primers were designed for $R$. rattus and $R$. norvegicus, as our study focused on these modern invaders, most primer pairs should also have amplified DNA from $R$. fuscipes and $H$. chrysogaster. The available sequences for these species do not contain the whole sequence length amplified in our study, but where sequences are available there are several primer pairs for which there are no variable sites in the primer binding sites in these species. It remains possible that some small bones that did not amplify were from these species, and that undocumented variation at primer sites meant that they did not amplify, however the most likely explanation for not detecting them at the site is because they were not present in the sample.

\section{The apparent absence of Rattus rattus}

It is perhaps surprising that we did not find any bones of $R$. rattus dating to the mid $19^{\text {th }}$ century There are several possible explanations for their absence. First, $R$. norvegicus is currently the primary rat present in urban wharf settings in Sydney, and it probably also dominated these areas historically. Second, the significantly different behavior and ecology of the two European rat species creates a bias in the chances of their preservation within archaeological sites. Rattus norvegicus is largely fossorial, nesting on the ground and burrowing in compost and under buildings, making it more likely to be preserved in archaeological deposits and in the foundations of demolished buildings. Rattus rattus is much more arboreal, climbing into rooves and trees, and these habitats and nesting locations will be less likely to preserve bones within the archeological record.

Finally, we still do not know the true arrival time and spread of $R$. rattus in Australia. There are reports of their presence in various places in Australia earlier (Banks, Hughes 2012; Long 2003), but their distribution and local population densities were not known. The historical record indicates that ship rats could have been present in Sydney over much of the period over which our samples originated (Banks et al. 2012; Curson, McCracken 1989). After 1900, their numbers could have increased, because they would have benefitted from the removal of so many $R$. norvegicus, but that does not explain their absence earlier. All of these hypotheses are non-exclusive, and depend on reliable species identifications by contemporary observers, so it will be hard to tease them apart without further data. Meanwhile, the rat haplotypes present in $19^{\text {th }}$ century Sydney provide a context to studies of the invasion of $R$. norvegicus in New Zealand as well as Australia. 
The most common haplotype recorded in the Sydney historical samples (and still recorded there today), is haplotype 9, the same as Norhap01 described from New Zealand by Russell et al. (2019). It is also the most common $R$. norvegicus haplotype found in modern samples from England (Haniza et al. 2015).

On the North Island of New Zealand, Norhap01 is the most common haplotype on the mainland and on various offshore islands including Campbell, Raoul, and Chatham that were served from $19^{\text {th }}$-century bases in Sydney. This observation is entirely as expected given the origins and destinations of most $19^{\text {th }}$ century trading goods, and the amount of shipping that passed between the port of Sydney and the North Island's main port in the Bay of Islands between 1820 and 1840 (Cumpston 1977; Richards, Chisholm 1992). Of the hundreds of ships from Britain engaged in trans-Tasman trade at that time, a high proportion were likely to have carried haplotype Norhap01/9, confirming a direct connection between Britain, Sydney and northern New Zealand. The first definite observations of Norway rats (presumably Norhap01) in the North Island were recorded in 1772, and they had established widespread populations there by the 1870 s.

\section{Rat invasions in New Zealand: South Island}

By contrast, a different $R$. norvegicus haplotype (Norhap02 of Russell et al. (2019) is resident in New Zealand's South Island, but has not been found in the North Island. Where could they have come from? Neither historical or modern samples have so far found any evidence of Norhap02 in Sydney, and elsewhere, this haplotype has been recorded only in China (Liu et al. 2012).

The difference in distributions of rat haplotypes on the two main islands of New Zealand is evidence that the two haplotypes of $R$. norvegicus arrived by different routes. How did that happen? Russell et al. (2019) hypothesized that Norhap02 arrived in the South Island via an independent invasion originating directly from China, bypassing Sydney. We found no traces of Norhap02 in Sydney, which is consistent with Russell's argument that these rats reached New Zealand via illegal, and therefore unrecorded, shipping connected with the fur trade well before 1820, as did house mice (King 2016).

Norhap03 of Russell et al. (2019), an unusual outlier not closely related to any other sample, was found in one modern sample in the southern port town of Bluff on the South Island. It also appeared as haplotype 5 among our Sydney specimens, suggesting a possible New Zealand origin for this individual or, of course, vice versa. We should note there is a discrepancy in the paper by Russell et al. (2019). The haplotypes Norhap03 and Norhap05 are swapped in the text description compared with the genbank entries. In our discussion we have gone with the text of the paper, rather than the genbank numbers.

House mice in Sydney

The small number of $M$. musculus samples that could be amplified from the Sydney collection contained only three mitochondrial haplotypes from clade E. All three are currently common and widespread in Australia, matching Australia.01 and Australia.04 of (Gabriel et al. 2011), domNZ.1 in New Zealand (Searle et al. 2009a), and BritIsl.5 in Britain (Searle et al. 2009b), which is probably where they all originated. 
We found no evidence of M. m. castaneus or M. m. musculus ancestry in Sydney. Ancestry from these two mouse subspecies has also yet to be detected in modern samples of mice from Australia (Gabriel et al. 2011), but both have been detected in New Zealand (King et al. 2016; King 2016; Searle et al. 2009a; Veale et al. 2018). Mice belonging to, or hybridised with, these two subspecies could either have come to New Zealand directly from China, or they could have arrived in Sydney at some point but failed to establish resident populations.

In previous papers we (Veale et al. 2018) speculated that some answers to these questions could be found by analysing the genetics of mice from the historical Sydney port region. Our results in this paper, though few, are consistent with previous suggestions that mice representing the two eastern subspecies travelled to New Zealand independently rather than via a Sydney established population. On the other hand, considering how many haplotypes appeared in this small sample form Sydney, and the many more known from larger samples collected from throughout New Zealand, it is perhaps rather early to conclude that no Asian mice ever reached Sydney. It remains possible that Asian mice, like Norhap02 rats, were present on ships that docked in Port Jackson harbour, but could not invade in the face of the incumbent advantage of the already resident conspecific populations thriving there (Fraser et al. 2015). If they did arrive, any such an event would be hard to detect now, and we have found no trace of them yet.

\section{Summary}

Norway rats and house mice both originated in Asia, and spread from there to reach western Europe by the mid 1700s. They arrived in time to accompany the explorers, traders and emigrants of the $18^{\text {th }}$ century European diaspora to reach almost every corner of the world inhabited by people. Both were carried by European and American ships among cargo, livestock and immigrants to Australia, and thence to New Zealand.

Historical DNA samples show that $R$. norvegicus dominated The Rocks area of Sydney in the $19^{\text {th }}$ Century, represented at that time by at least six mitochondrial haplotypes. The most common haplotype we identified from Sydney (here numbered 9) is also found in England and on New Zealand's North Island, where it is called Norhap01. A second haplotype (Norhap02) of $R$. norvegicus, found only on New Zealand's South Island and in China, was not found in Sydney. The uncertainties of the dating of the samples prevent detection of any trends in their genetic diversity, or of whether there was any turnover of rat haplotypes during this period.

The genetic diversity and mitochondrial ancestry of living $R$. norvegicus in Australia has been insufficiently studied, probably because this species is primarily confined to urban environments, so has had minimal ecological impacts and significance to conservation in less modified environments. Future studies both in Sydney and across Australia, similar to that of Puckett et al. (2016) both on its mitochondria, and its nuclear genome, are needed to collect larger samples in which to search for rarer haplotypes. These could help us understand the local population histories and evolution of $R$. norvegicus haplotypes since colonization. Our small sample of $19^{\text {th }}$ century house mice from Sydney identified only the western subspecies $M u s$ musculus domesticus as having established there.

Both Norway rats and house mice carry in their genomes evidence of unknown, illegal shipping movements in the southwestern Pacific during the 18th and 19th centuries, which are invisible to documentary records. Fragmentary evidence supports our previous hypothesis that fur sealers ignored regulations prohibiting direct trading of sealskins in Canton, at least while the return justified the risk. The possibility of illegal return cargoes by sealers carrying provisions 
infested with Chinese rodents is an attractive explanation of how two eastern subspecies of mice (M. m. castaneus and M. m. musculus), along with Norhap02 of $R$. norvegicus, could have got to the South and Stewart Islands without passing through Sydney. The absence of these three taxa in Sydney, and their presence around locations of early and intense sealing activities in New Zealand, confirm a hitherto unknown short but important clandestine connection with China over about 20 years after 1800 . This independent evidence of a direct, and illegal, China connection casts new light on our understanding of commerce in early colonial New Zealand.

\section{Acknowledgements}

Permission to access the historic collections and their accompanying database, and support during the collection of samples, was granted by the Place Management NSW (formerly Sydney Cove Authority). Funding for the genetics analysis was provided by Waikato University's Strategic Investment Fund, courtesy Prof Bruce Clarkson. Thanks to the State Library of NSW for permission to reproduce the photo in Figure 4. The general description of those pictured in Figure 4 was kindly provided by Dr Peter Banks, a rodent specialist at the University of Sydney.

\section{References}

Anon. (1803) The Sydney Gazette and New South Wales Advisor. Sydney, Saturday 2 April $1803, \mathrm{p} 3$.

Anon. (1804) The Sydney Gazette and New South Wales Advisor, Sunday 2 December 1804 edn.,

Archer M (1984) Effects of humans on the Australian vertebrate fauna. In: Archer $M$ and Clayton G (eds) Vertebrate Zoogeography and Evolution in Australasia'. Hesperian Press, Perth, pp. 151-161

Atkinson UAE (1973) Spread of the ship rat (Rattus r. rattus L.) III New Zealand. Journal of the Royal Society of New Zealand 3:457-472

Banks P, Cleary G, Dickman C (2012) Sydney's bubonic plague outbreak 1900-1910: a disaster for foreshore wildlife? Australian Zoologist 35:1033-1039

Banks P, Hughes N (2012) A review of the evidence for potential impacts of black rats (Rattus rattus) on wildlife and humans in Australia. Wildlife Research 39:78

Brouat C, Tollenaere C, Estoup A, et al. (2014) Invasion genetics of a human commensal rodent: The black rat Rattus rattus in Madagascar. Molecular Ecology 23

Clutterbuck JB (1850) Port Phillip in 1849. John W. Parker, London

Combs M, Puckett E, Richardson J, et al. (2017) Spatial population genomics of the brown rat (Rattus norvegicus) in New York City. Molecular Ecology 27

Cox M, Cox C (2001) Use of habitat by the black rat (Rattus rattus) at North Head, New South Wales: An observational and experimental study. Austral Ecology 25:375-385

Cumpston JS (1977) Shipping arrivals and departures Sydney, 1788-1825. Roebuck Society Publication 22, Canberra,

Curson P, McCracken K (1989) Plague in Sydney: Anatomy of an Epidemic. New South Wales University Press, Kensington

Davies P, Garvey J (2013) Early Zooarchaeological Evidence for Mus musculus in Australia. International Journal of Osteoarchaeology 23:106-111

Fraser CI, Banks SC, Waters JM (2015) Priority effects can lead to underestimation of dispersal and invasion potential. Biological Invasions 17:1-8 
Gabriel SI, Mathias ML, Searle JB (2015) Of mice and the 'Age of Discovery': the complex history of colonization of the Azorean archipelago by the house mouse (Mus musculus) as revealed by mitochondrial DNA variation. Journal of Evolutionary Biology 28:130145

Gabriel SI, Stevens MI, Mathias MD, et al. (2011) Of Mice and 'Convicts': Origin of the Australian House Mouse, Mus musculus. Plos One 6

Geffen E, Rowe KC, Yom-Tov Y (2011) Reproductive Rates in Australian Rodents Are Related to Phylogeny. PLOS ONE 6:e19199

Genovesi P, Carnevali L, Alonzi A, et al. (2012) Alien mammals in Europe: Updated numbers and trends, and assessment of the effects on biodiversity. Integrative zoology 7:247-53

Hainsworth DR (1972) The Sydney traders: Simeon Lord and his contemporaries. Cassell Australia, Melbourne

Haniza MZ, Adams S, Jones EP, et al. (2015) Large-scale structure of brown rat (Rattus norvegicus) populations in England: effects on rodenticide resistance. PeerJ 3

Howald G, Donlan CJ, Galvan JP, et al. (2007) Invasive rodent eradication on islands. Conserv. Biol. 21:1258-1268

Jones EP, Eager HM, Gabriel SI, et al. (2013) Genetic tracking of mice and other bioproxies to infer human history. Trends in Genetics 29:298-308

Jones EP, Jóhannesdóttir F, Richards MB, et al. (2011) The expansion of the house mouse into northern-western Europe. Journal of Zoology 283:257-268

Jones EP, Skirnisson K, McGovern TH, et al. (2012) Fellow travellers: a concordance of colonization patterns between mice and men in the North Atlantic region. Bmc Evolutionary Biology 12

Kearse M, Moir R, Wilson A, et al. (2012) Geneious Basic: An integrated and extendable desktop software platform for the organization and analysis of sequence data. Bioinformatics 28:1647-1649

Kelly M (1997) Anchored in a small cove: A history and archaeology of the Rocks, Sydney. Sydney Cove Authority, Sydney

Kelly M, Mackay R, Karskens G (1996) Cumberland/Gloucester Streets Site: Archaeological Investigation 1994. Sydney Cove Authority, Sydney,

King C, Alexander A, Chubb T, et al. (2016) What can the geographic distribution of mtDNA haplotypes tell us about the invasion of New Zealand by house mice Mus musculus? Biological Invasions 18:1551-1565

King CM (2016) How genetics, history and geography limit potential explanations of invasions by house mice Mus musculus in New Zealand. Biological Invasions 18:1533-1550

Li Y, Fujiwara K, Osada N, et al. (2020) House mouse Mus musculus dispersal in East Eurasia inferred from 98 newly determined complete mitochondrial genome sequences. Heredity

Liu J, Liu DY, Chen W, et al. (2012) Genetic analysis of hantaviruses and their rodent hosts in central-south China. Virus Research 163:439-447

Long JL (2003) Introduced Mammals of the World: Their History, Distribution and Influence. CSIRO Publishing, Melbourne

McLean FS (1955) The history of plague in New Zealand. The New Zealand Medical Journal $54: 131-143$

Menkhorst PW (1995) Brown rat, Rattus norvegicus. In: Menkhorst PW (ed) Mammals of Victoria. Distribution, Ecology and Conservation. Oxford University Press, Melbourne, pp. $223-230$

Paradis E (2010) pegas: an $\mathrm{R}$ package for population genetics with an integrated-modular approach. Bioinformatics 26:419-420

Paradis E, Claude J, Strimmer K (2004) APE: Analyses of Phylogenetics and Evolution in R language. Bioinformatics 20:289-290 
Paradis E, Schliep K (2019) ape 5.0: an environment for modern phylogenetics and evolutionary analyses in R. Bioinformatics 35:526-528

Pimentel D, Lach L, Zuniga R, et al. (2000) Environmental and Economic Costs of Nonindigenous Species in the United States. Bioscience 50:53-65

Puckett EE, Park J, Combs M, et al. (2016) Global population divergence and admixture of the brown rat (Rattus norvegicus). Proceedings of the Royal Society B-Biological Sciences 283

Richards R, Chisholm J (1992) Bay of Islands shipping arrivals and departures 1803 - 1840. Paremata Press, Wellington,

Robins JH, Hingston M, Matisoo-Smith E, et al. (2007) Identifying Rattus species using mitochondrial DNA. Molecular Ecology Notes 7:717-729

Robinson A, Kemper C, Medlin G, et al. (2000) The Rodents of South Australia. Wildlife Research 27:379-404

Rose T, Banks P (2007) Impacts of black rats Rattus rattus across an urban/bushland interface at Sydney's North Head. pp. 66-75

Rozen S, Skaletsky H (2000) Primer3 on the WWW for general users and for biologist programmers. Methods Mol Biol 132:365-86

Russell JC, Innes JG (2021) Family Muridae: Norway Rats. In: M. KC and Forsyth DM (eds) The Handbook of New Zealand Mammals 3rd edn. CSIRO Publishing, Melbourne, pp. 166-176

Russell JC, Robins JH, Fewster RM (2019) Phylogeography of Invasive Rats in New Zealand. Frontiers in Ecology and Evolution 7

Searle JB (2008) The genetics of mammalian invasions: a review. Wildlife Research 35:185192

Searle JB, Jamieson PM, Gunduz I, et al. (2009a) The diverse origins of New Zealand house mice. Proceedings of the Royal Society B-Biological Sciences 276:209-217

Searle JB, Jones CS, Gündüz İ, et al. (2009b) Of mice and (Viking?) men: phylogeography of British and Irish house mice. Proceedings of the Royal Society B: Biological Sciences 276:201-207

Seebeck J, Menkhorst P (2000) Status and conservation of the rodents of Victoria. Wildlife Research 27:357-369

Smith H, Dickman C, Banks P (2016) Nest Predation by Commensal Rodents in Urban Bushland Remnants. PloS one 11:e0156180

Veale AJ, Russell JC, King CM (2018) The genomic ancestry, landscape genetics and invasion history of introduced mice in New Zealand. Royal Society Open Science 5

Watts CHS, Aslin HJ (1981) The Rodents of Australia. Angus \& Robertson, Sydney

Wickham H (2016) ggplot2: Elegant Graphics for Data Analysis. Springer-Verlag, New York

Wood J, Herrera M, Scofield R, et al. (2016) Origin and timing of New Zealand's earliest domestic chickens: Polynesian commensals or European introductions? Royal Society Open Science 3:160258 
Tables

Table 1 Novel PCR primers designed for amplification of historical DNA from the mitochondrial D-loop for either Rattus $s p$. or Mus musculus.

\begin{tabular}{|l|l|c|}
\hline Forward primer & Reverse Primer & $\begin{array}{l}\text { Product } \\
\text { length }\end{array}$ \\
\hline $\begin{array}{l}\text { Rat_dloop_1F } \\
\text { RCRTGCTTATATGCTTGGGG }\end{array}$ & $\begin{array}{l}\text { Rat_dloop_1R } \\
\text { CCACCATCAACACCCAAAGC }\end{array}$ & $128 \mathrm{bp}$ \\
\hline $\begin{array}{l}\text { Rat_dloop_2F } \\
\text { TGYATGTCTRATAACACAGATATGTCT }\end{array}$ & $\begin{array}{l}\text { Rat_dloop_2R } \\
\text { CCCAAGCATATAAGCAYGYAATATAT }\end{array}$ & $140 \mathrm{bp}$ \\
\hline $\begin{array}{l}\text { Rat_dloop_3F } \\
\text { GGGCGGGTTGTTGATTTCAC }\end{array}$ & $\begin{array}{l}\text { Rat_dloop_3R } \\
\text { TCTGTGTTATYAGACATRCACCAT }\end{array}$ & $116 \mathrm{bp}$ \\
\hline $\begin{array}{l}\text { Rat_dloop_4F } \\
\text { TGGCCCTGAAGTAAGAACCAG }\end{array}$ & $\begin{array}{l}\text { Rat_dloop_4R } \\
\text { GAAATCAACAACCCGCCCAC }\end{array}$ & $109 \mathrm{bp}$ \\
\hline $\begin{array}{l}\text { Rat_dloop_5F } \\
\text { KGAAGGCATCCGAAAATTAAAAA }\end{array}$ & $\begin{array}{l}\text { Rat_dloop_5R } \\
\text { ACTTCAGGGCCATCAATTG }\end{array}$ & $140 \mathrm{bp}$ \\
\hline $\begin{array}{l}\text { Mus_dloop_1F } \\
\text { CCACCACCAGCACCCAAA }\end{array}$ & $\begin{array}{l}\text { Mus_dloop_1R } \\
\text { TGCTTGGGGAAAATAGTTTAATGT }\end{array}$ & $115 \mathrm{bp}$ \\
\hline $\begin{array}{l}\text { Mus_dloop_2F } \\
\text { AGCATATAAGCWAGTACATTWAATCA }\end{array}$ & $\begin{array}{l}\text { Mus_dloop_2R } \\
\text { GGTGTATGTCAGATAACACAGA }\end{array}$ & $139 \mathrm{bp}$ \\
\hline $\begin{array}{l}\text { Mus_dloop_3F } \\
\text { TCTGACATACACCATACAGTCA }\end{array}$ & $\begin{array}{l}\text { Mus_dloop_3R } \\
\text { GGAGCGAGAAGAGGGGCAT }\end{array}$ & $128 \mathrm{bp}$ \\
\hline $\begin{array}{l}\text { Mus_dloop_4F } \\
\text { GGGTCTAATCAGCCCATGACC }\end{array}$ & $\begin{array}{l}\text { Mus_dloop_4R } \\
\text { TGTGCTGTCCTTTCATGCCT }\end{array}$ & $109 \mathrm{bp}$ \\
\hline $\begin{array}{l}\text { Mus_dloop_5F } \\
\text { CGGTGAAGAATCATTAGTCCGC }\end{array}$ & $\begin{array}{l}\text { Mus_dloop_5R } \\
\text { TTGGCAYTAAGAGGAGGGGG }\end{array}$ & $128 \mathrm{bp}$ \\
\hline $\begin{array}{l}\text { Mus_dloop_6F } \\
\text { TTCTAGTAGTTCCCAAAATATGACT }\end{array}$ & $\begin{array}{l}\text { Mus_dloop_6R } \\
\text { TGCTTTGTTATTAAGCTACATTAACT }\end{array}$ & $139 \mathrm{bp}$ \\
\hline
\end{tabular}




\section{Figures}

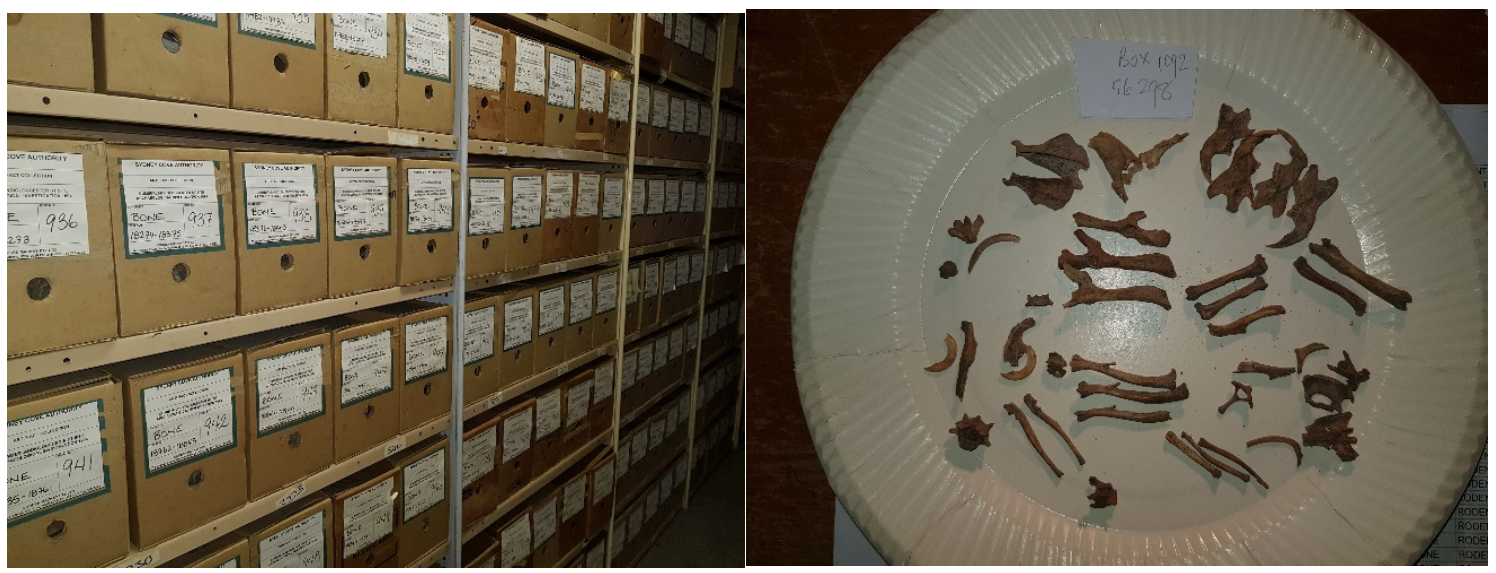

Figure 1. A, left. Storage facility for the bones archive. B, right. Identifying rat bones from Box 1092, Bag 56298. Photos by C M King

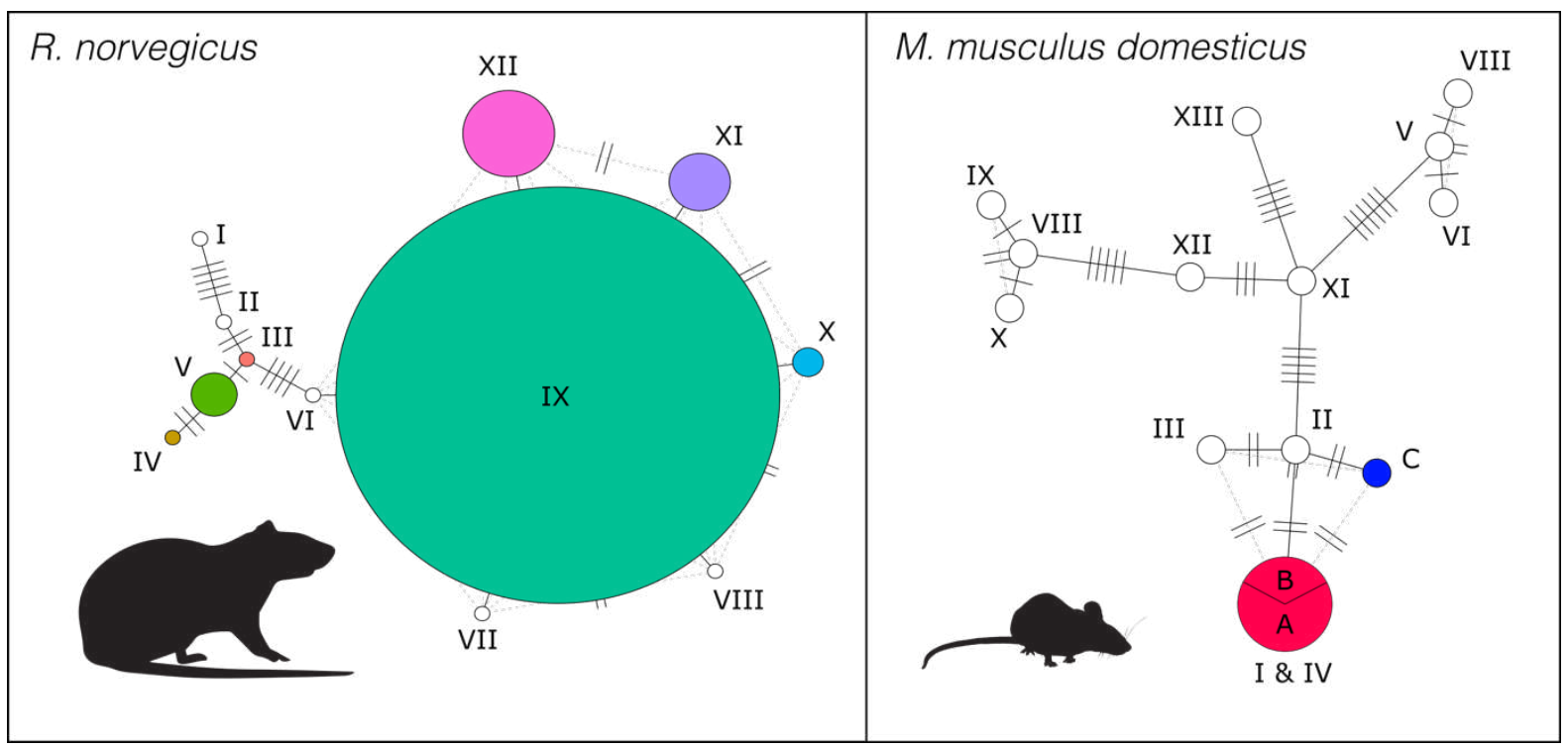

Figure 2. Left: Haplotype network of R. norvegicus D-loop haplotypes. Right:haplotypes of M. m. domesticus.. For the R. norvegicus network, haplotypes not recorded in our study but found by Russell et al 2019 in New Zealand are uncoloured. For the M. m. domesticus network, haplotypes not recorded in our study but found by Gabriel et al. 2011 in Australia are uncoloured. Haplotype numbers for the M. m. domesticus network match the haplotypes listed in Gabriel et al. 2011. Haplotypes A\& B are separated by 1 bp but this variable site was not included in Gabriel et al., 2011 therefore is not displayed here. Circle sizes proportional to numbers of specimens, to maximum 25 for haplotype 9 of $\mathrm{R}$. norvegicus. 


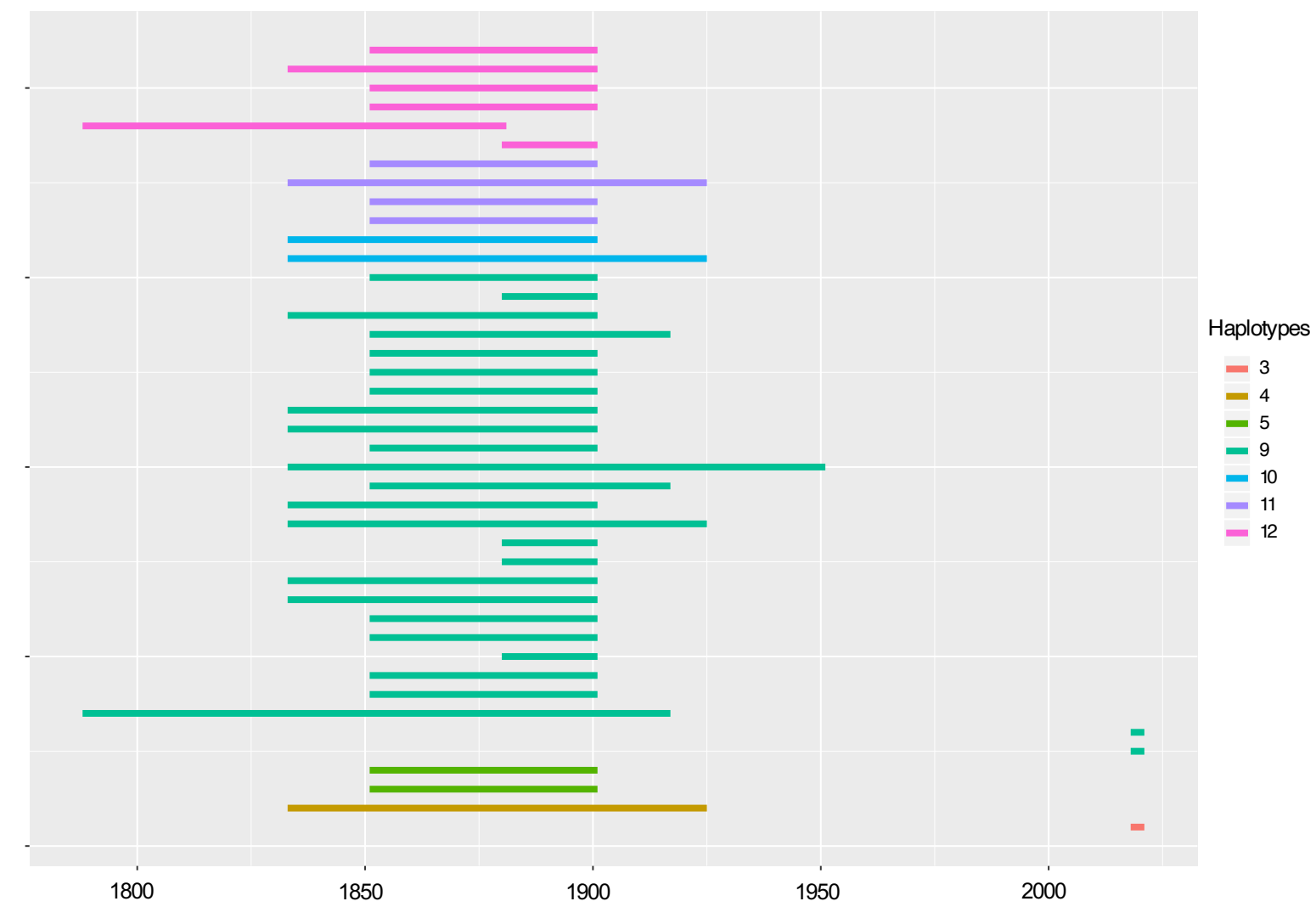

Figure 3 The time windows for each of the R. norvegicus samples from which historical DNA was sequenced, and their haplotype numbers. Modern samples at far right. 


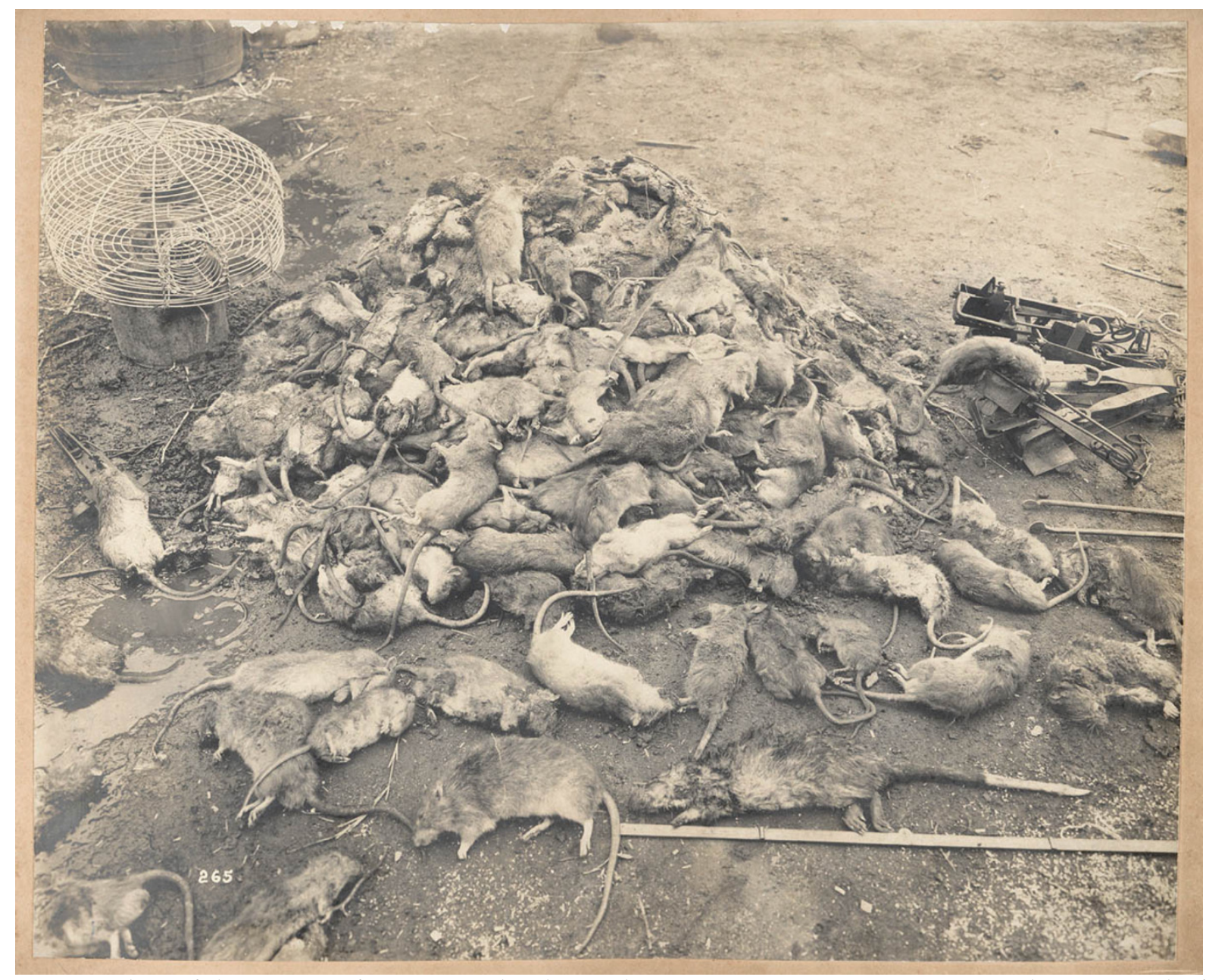

Figure 4 A heap of about 600 rats, from "Views taken during Cleansing Operations, Quarantine Area, Sydney, 1900, Vol V/ under the supervision of Mr George McCredie, FIA NSW, Mitchell Library, State Library of NSW Call No PXE94/265 


\section{Figures}
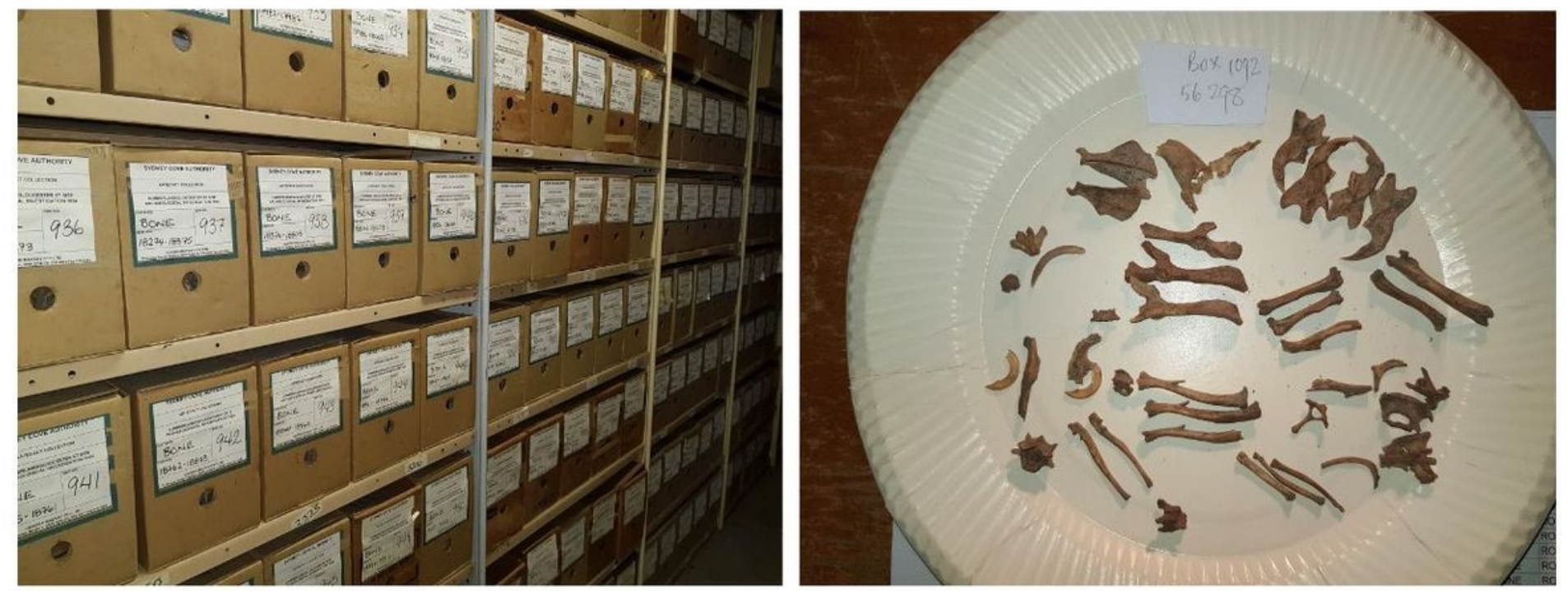

\section{Figure 1}

A, left. Storage facility for the bones archive. B, right. Identifying rat bones from Box 1092, Bag 56298. Photos by C M King

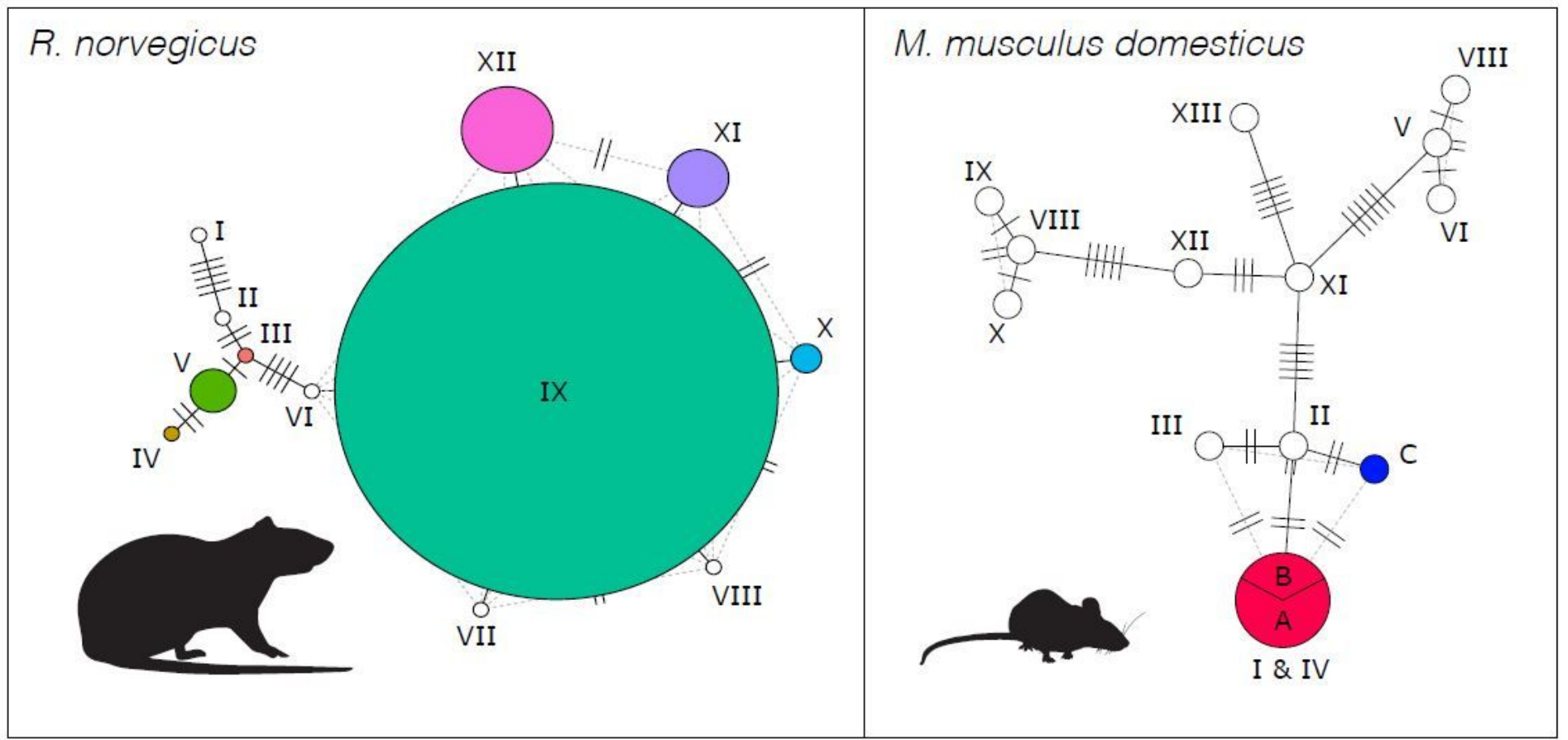

Figure 2

Left: Haplotype network of R. norvegicus D-loop haplotypes. Right:haplotypes of M. m. domesticus.. For the R. norvegicus network, haplotypes not recorded in our study but found by Russell et al 2019 in New 
Zealand are uncoloured. For the M. m. domesticus network, haplotypes not recorded in our study but found by Gabriel et al. 2011 in Australia are uncoloured. Haplotype numbers for the M. m. domesticus network match the haplotypes listed in Gabriel et al. 2011. Haplotypes A \& B are separated by 1 bp but this variable site was not included in Gabriel et al., 2011 therefore is not displayed here. Circle sizes proportional to numbers of specimens, to maximum 25 for haplotype 9 of R. norvegicus.

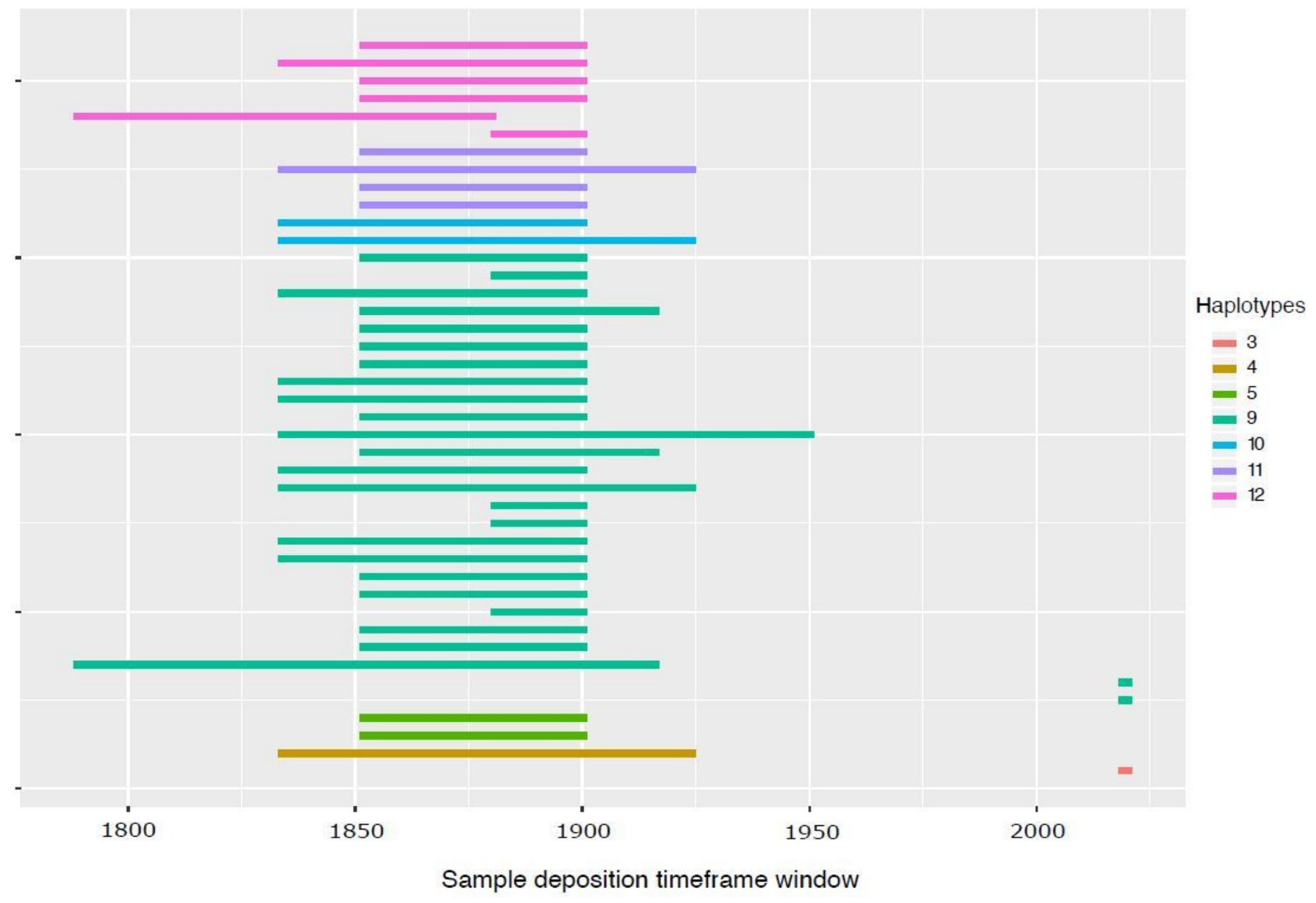

\section{Figure 3}

The time windows for each of the R. norvegicus samples from which historical DNA was sequenced, and their haplotype numbers. Modern samples at far right. Sample 


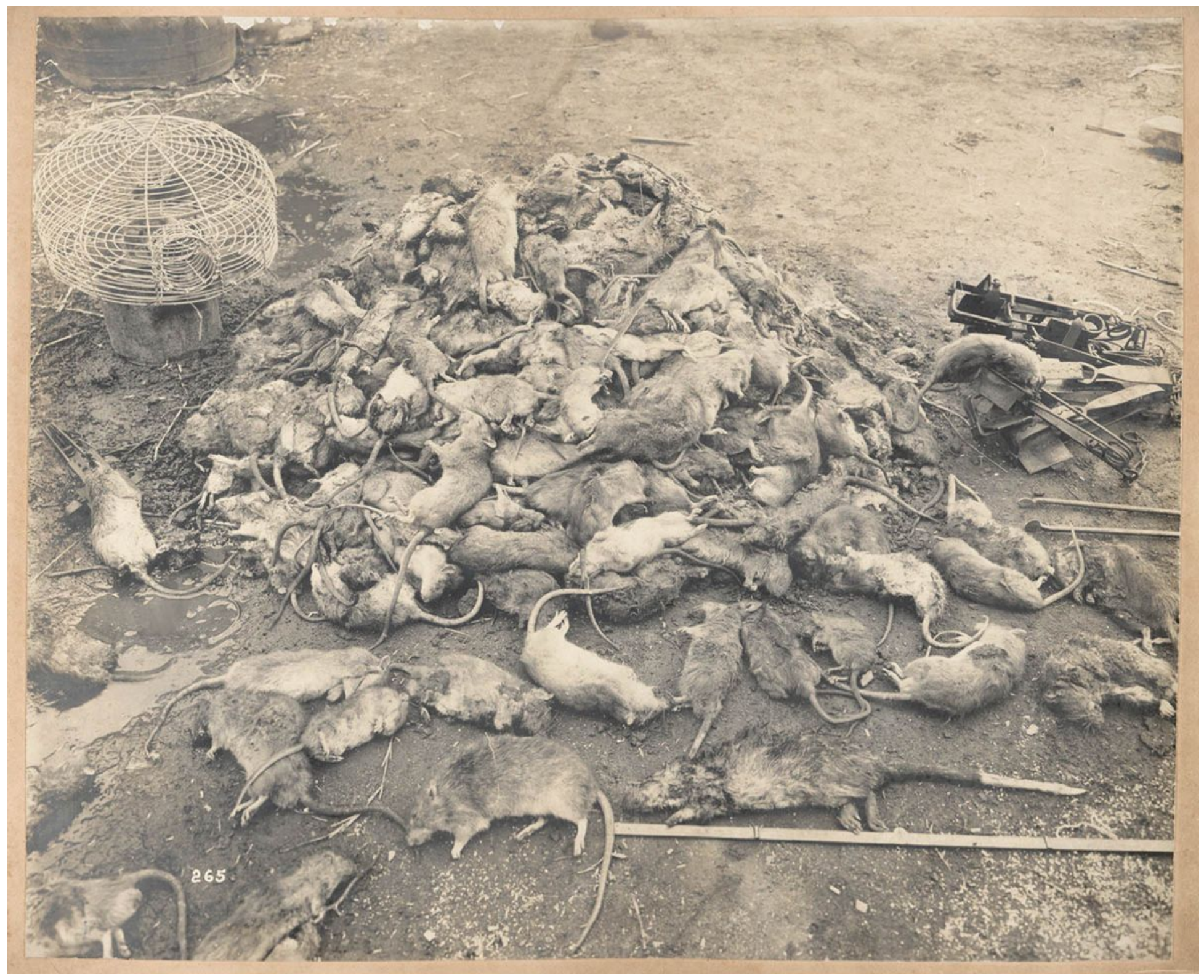

\section{Figure 4}

A heap of about 600 rats, from "Views taken during Cleansing Operations, Quarantine Area, Sydney, 1900, Vol V / under the supervision of Mr George McCredie, FIA NSW, Mitchell Library, State Library of NSW Call No PXE94/265 